\title{
Coralline algae as environmental indicators: a case study from the Attard member (Chattian, Malta)
}

\author{
Francesca QUARANTA \\ Università di Genova, \\ Dipartimento per lo Studio del Territorio e delle sue Risorse, \\ Corso Europa 26, I-16132 Genova (Italy) \\ f.quaranta@libero.it \\ Laura TOMASSETTI
}

La Sapienza Università di Roma, Dipartimento di Scienze della Terra, piazzale Aldo Moro 5, I-00185 Roma (Italy) laura.tomassetti@uniroma1.it

Grazia VANNUCCI

Università di Genova, Dipartimento per lo Studio del Territorio e delle sue Risorse, Corso Europa 26, I-16132 Genova (Italy) vannucci@dipteris.unige.it

Marco BRANDANO

La Sapienza Università di Roma, Dipartimento di Scienze della Terra, piazzale Aldo Moro 5, I-00185 Roma (Italy) and Istituto di Geologia Ambientale e Geoingegneria (IGAG) CNR, cp 10 00016, area della Ricerca di Roma 1, Via Salaria Km 29,300, Monterotondo Stazione, I-00185 Roma (Italy) marco.brandano@uniroma1.it

Quaranta F., Tomassetti L., Vannucci G. \& Brandano M. 2012. - Coralline algae as environmental indicators: a case study from the Attard member (Chattian, Malta). Geodiversitas 34 (1): 151-166. http://dx.doi.org/10.5252/g2012n1a9

\section{ABSTRACT}

We investigated the distribution of the red algae assemblages along the depositional profile of the Attard carbonate ramp of Malta (Chattian). The Attard member is ascribed to the Lower Coralline Limestone Formation characterized by 4 members: Maghlaq, Attard, Xlendi and Il Mara. Coralline 
KEY WORDS

Coralline algae,

Oligocene,

carbonate ramp, paleoecology, Malta. algae are present in the inner and middle ramp environments of the Attard member. Sporolithaceans and melobesioids dominate the inner ramp, while mastophoroids and peyssonneliaceans are subordinate. In the middle ramp the association of red algae is characterized by an increase of sporolithacenas and a decrease of melobesioids, mastophoroids and peyssonneliaceans. These assemblages are related to the depth gradient existing from the inner relatively shallow to the progressively deeper middle ramp. However, transportation of red algae down slope may have had an effect on the red algae associations. The shape, morphology and structure of rhodoliths in the inner ramp environment are indicative of high-energy conditions. Nevertheless localized sectors of inner ramp are characterized by morphologies typical of low energy probably related to the presence of areas colonized by seagrass. Rhodoliths from the middle ramp have characteristics of moderately highenergy. The presence of Sporolithon Heydrich and Lithoporella (Foslie) Foslie indicates that the production of carbonate took place under tropical conditions. We suggest that the $\mathrm{Mg} / \mathrm{Ca}$ ratios may had a control on the flourishing of coralline algae in the Oligocene carbonate factories situated in oligo- to mesotrophic conditions, whereas during Early to Middle Miocene times the trophic conditions were one of the main controlling factor.

\section{RÉSUMÉ}

Les algues corallines, marqueuses des environnements : l'exemple du Membre Attard (Chattien), Malte.

Nous avons étudié la répartition des associations d'algues rouges le long du profil sédimentaire de la rampe carbonatée d'Attard (Chattien) de l'île de Malte. Le Membre Attard appartient à la Formation des Calcaires coralligènes inférieurs, subdivisée en quatre membres: Maghlaq, Attard, Xlendi et Il Mara. Les algues corallines sont présentes dans les ceintures internes et moyennes de la rampe. Les sporolithacées et les mélobésioïdées dominent dans la rampe interne tandis que les mastophorö̈dées et les peyssonneliacées sont minoritaires. Au niveau de la rampe moyenne, les associations d'algues rouges se caractérisent par une augmentation de la fréquence des sporolithacées et une réduction corrélative des mélobésioïdées, des mastophoroïdées et des peyssonneliacées. Au sein du Membre Attard, la composition des associations varie selon leur position sur le gradient proximal-distal (en fait, la profondeur) qui existe entre les parties internes à moyennes de la rampe. On notera toutefois que des remobilisations de sédiments le long de la pente peuvent perturber le contenu des associations. La forme, la morphologie et la structure des rhodolithes de la rampe interne portent la signature d'un environnement de haute énergie. Cependant, quelques secteurs restreints de la rampe interne se caractérisent par des morphologies typiques de conditions de basse énergie, sans doute en raison de la colonisation du fond par des herbiers. Les caractères des rhodolithes de la rampe moyenne sont caractéristiques de conditions de moyenne à haute énergie. La cooccurrence de Sporolithon Heydrich et de Lithoporella (Foslie) Foslie nous indique que la production carbonatée s'est faite sous climat tropical. Nous suggérons enfin qu'à l'Oligocène, au sein des "usines " à carbonates, l'abondance des algues corallines dépendait également du rapport $\mathrm{CA} / \mathrm{Mg}$, que l'on soit en conditions méso- ou oligotrophes, alors qu'au Miocène inférieur à moyen, les conditions trophiques s'imposaient comme contraintes majeures. 


\section{INTRODUCTION}

The corallines have a thallus that calcifies early which allows them to be readily preserved as fossils. They grow as crustose or arborescent forms. The crustose forms can form rhodoliths, free-living, unattached nodules consisting predominantly of superimposed thalli of calcareous red algae (Bosellini \& Ginsburg 1971; Bosence 1983a; Foster et al. 1997; Marrack 1999). Other organisms, such as bryozoans, annelids and encrusting foraminifera may contribute to the growth of the nodules. Rhodoliths are a valuable source of paleoenvironmental information because of their sensitivity to ecological dynamics. In fact, changes in the taxonomical composition and internal structure of rhodoliths are closely related to their depositional setting (Bosence 1983b; Basso 1998; Brandano et al. 2005). Coralline algae are among the main producers of sediment in photic carbonate factories. They are important contributors to Cretaceous, Paleocene and Eocene platform deposits, and become dominant especially on OligoMiocene carbonate ramps (Carannante et al. 1995; Pedley 1998; Aguirre et al. 2000; Halfar \& Mutti 2005; Aguirre et al. 2007).

This paper documents the distribution of the red algal assemblages along the depositional profile of the Attard carbonate ramp of Malta (Brandano et al. 2009a). Coralline algae are present in the inner and middle ramp environments.

\section{GEOLOGICAL, STRATIGRAPHICAL AND SEDIMENTOLOGICAL SETTING}

The Maltese islands are part of a wide carbonate ramp on the distal segment of the Late Oligocene to Miocene African continental margin (Fig. 1). The sedimentary succession of the Maltese Islands is characterized by four major lithostratigraphic units (Fig. 2) (Pedley 1978; Di Geronimo et al. 1981; Carbone et al. 1987). The basal unit is the Lower Coralline Limestone Formation (Chattian) made up of heterozoan-dominated skeletal rudstones and packstones deposited in inner to outer ramp settings. This lithostratigraphic unit is followed by hemipelagic planktonic wackestones of the Globige- rina Limestone Formation (Aquitanian-Langhian). This unit is overlain by hemipelagic clay- to marlstones of the Blue Clay Formation (Serravallian-early Tortonian). This fine-grained formation is overlain unconformably by the photozoan carbonates of the Upper Coralline Limestone Formation (Tortonian to Messinian). The coralline algae studied here were sampled in the Attard member of the Lower Coralline Limestone Formation. This formation has a minimum thickness of $50 \mathrm{~m}$. Pedley (1978) subdivided the formation into four lithological members (Fig. 2). The first member is the Maghlaq Member deposited in a sheltered lagoon, that with progressive submergence was colonized by rhodolithic algae of the overlying Attard member. This member is overlain by intertidal cross-bedded units of the Xlendi Member. The uppermost Mara Member is characterized by beds with bryozoa and Lepidocyclina Gümbel, 1870.

\section{THE ATTARD CARBONATE RAMP}

The depositional profile of the Attard carbonate ramp (Fig. 3) is consistent with a homoclinal ramp (Brandano et al. 2009a).

The composition and facies of the Attard member indicate that all its inner ramp environments were laid down in a high-energy, shallow-water setting, influenced by wave action. Brandano et al. (2009a, b) distinguish three lithofacies: 1) porcellaneous foraminiferal grainstones and packstones containing relatively well sorted and highly abraded biogenic components; other important components include rounded and micritised bioclasts. Compound crossbedding is characteristic of this lithofacies; it represents medium-scale, two-dimensional cross-bedded subaqueous dunes produced by the migration of superimposed small bedforms (sensu Ashley 1990) in a high-energy nearshore environment.

This facies was deposited in a very-shallow-water setting, as indicated by abundant porcellaneous foraminifera and the sedimentary structures. 2) These pass downdip into unsorted rhodolith floatstones and rudstones. This facies is crudely stratified and characterized by an abundance of small rhodoliths. Other components are coralline algal debris and crusts, clasts of echinoids, gastropods, rare coral colonies, and porcelaneous and encrusting foraminifera. 


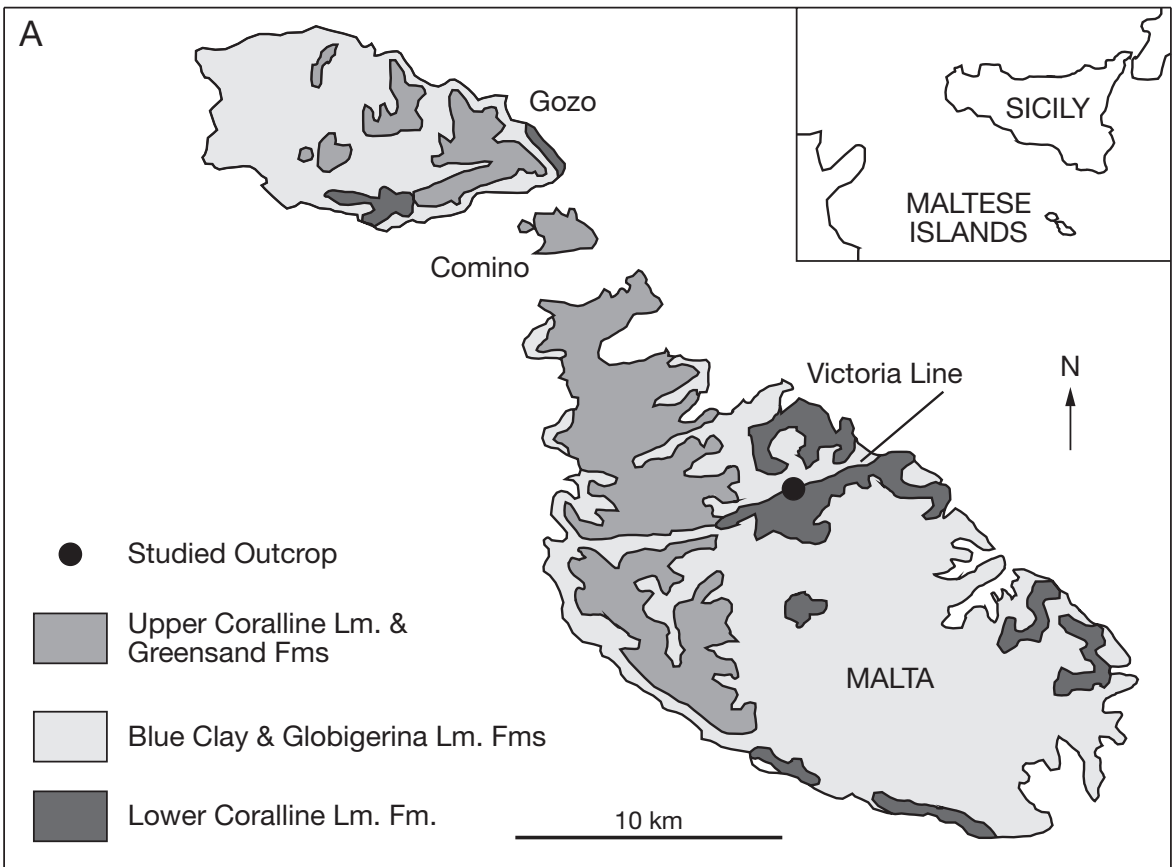

B

\begin{tabular}{|c|c|c|c|}
\hline \multicolumn{2}{|r|}{ Stratigraphy } & \multicolumn{2}{|c|}{ Lithostratigraphic units } \\
\hline \multirow{3}{*}{ 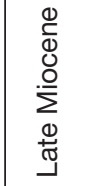 } & MESSINIAN & \multirow{2}{*}{$\begin{array}{l}\text { Upper Coralline } \\
\text { Lm. Fm. (10-80 m) }\end{array}$} & \\
\hline & \multirow{2}{*}{ TORTONIAN } & & \\
\hline & & Greensand Fm. (0-11 m) & \\
\hline \multirow{2}{*}{$\begin{array}{ll}\frac{0}{0} & \frac{1}{0} \\
\frac{0}{0} & 0 \\
\frac{0}{\Sigma} & \frac{0}{2} \\
\frac{0}{\Sigma}\end{array}$} & SERRAVALLIAN & \multirow[t]{2}{*}{$\begin{array}{l}\text { Blue Clay Fm. } \\
(18-75 \mathrm{~m})\end{array}$} & \\
\hline & LANGHIAN & & \\
\hline \multirow{3}{*}{ 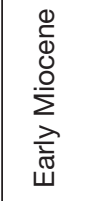 } & BURDIGALIAN & \multirow{3}{*}{$\begin{array}{l}\text { Globigerina } \\
\text { Limestone } \\
\text { Formation } \\
(10-70 \mathrm{~m})\end{array}$} & \multirow{3}{*}{$\begin{array}{l}\text { II-Mara Mb. (0-20 m) } \\
\text { Xlendi Mb. (0-22 m) }\end{array}$} \\
\hline & & & \\
\hline & AQUITANIAN & & \\
\hline 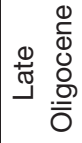 & CHATTIAN & $\begin{array}{l}\text { Lower Coralline } \\
\text { Limestone Fm. } \\
\qquad(>50 \mathrm{~m})\end{array}$ & $\begin{array}{l}\text { Attard Mb. }(10-15 \mathrm{~m}) \\
\text { Maghlaq Mb. }(>38 \mathrm{~m})\end{array}$ \\
\hline
\end{tabular}

FIG. 1. - Geological setting of Malta (from Brandano et al. 2009a). Abbrevations: Fm., formation; Lm., limestone. 
Porcellaneous foraminiferal grainstone to packstone

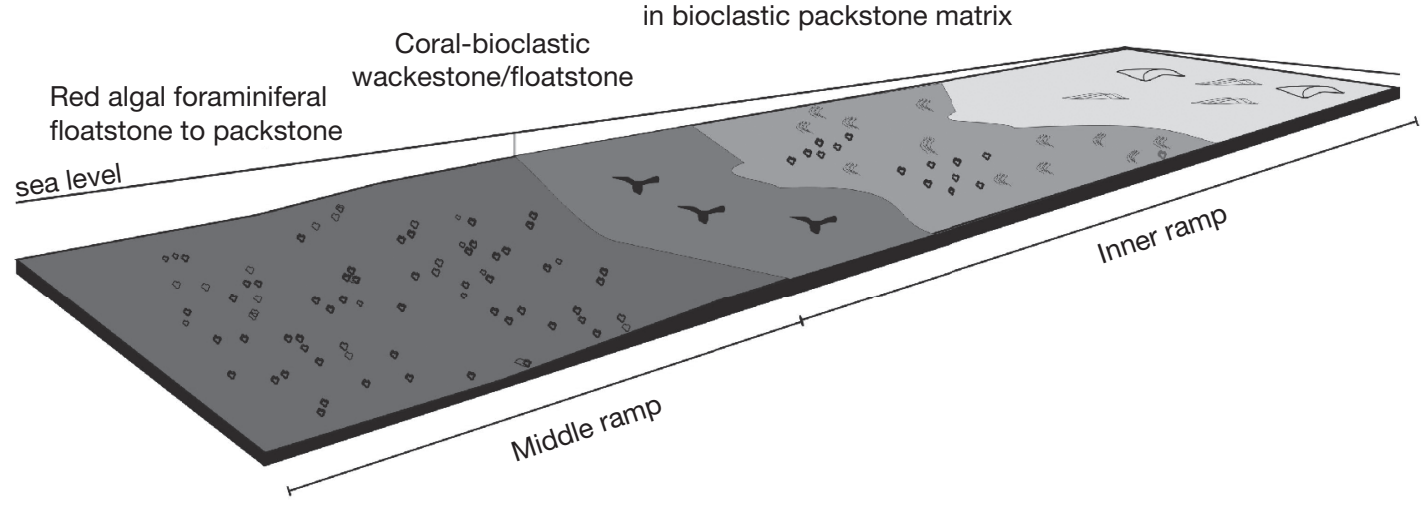

Fig. 2. - Lithostratigraphic succession of Malta (modified from Pedley 1978).

The sediments and their composition suggest a depositional environment colonized by seagrass. 3) Evidence for the existence of seagrass meadows includes the absence of sorting and the presence of sedimentary structures due to baffling, trapping and substrate stabilization (Pomar et al. 2002) and the occurrence of epiphytic forms (Borelis de Montfort, 1808, Archaias de Montfort, 1808, Sorites Ehrenberg, 1839, Planorbulina mediterranensis d'Orbigny, 1826, Carpenteria Gray, 1858, Lobatula lobatula (Walker \& Jacob, 1798)) (Brandano et al. 2009a, b). These deposits interfingered with adjacent areas containing scattered corals (coral-bioclastic wackestones/floatstones). The middle ramp lithofacies consists of massive red algal and benthonic foraminiferal floatstones and packstones that in addition to rhodoliths, include nodules and branches of coralline algae, larger benthic foraminifera (LBF), bryozoans, and echinoid and pectinid fragments. The lithofacies of the middle ramp were deposited in the oligophotic zone. Sediment accumulation is considered to be a combination of in situ deposits and of material swept from the shallower inner ramp by currents (Brandano et al. 2009a).

\section{METHODS}

Thirty-four samples of rhodoliths were collected along the ramp profile of the Attard member
(Brandano et al. 2009a) (Fig. 3). A total of 34 thin sections were made and studied to identify the red algae to the most precise taxonomic level possible. The sampling of calcareous red algae was semiquantitative, samples were picked horizontally at intervals of $100 \mathrm{~cm}$. Rhodolith samples were taken from the rhodolith and rudstone facies (inner ramp) and from the red algal and benthonic foraminiferal floatstones and packstone facies (middle ramp).

The relative abundance of the several species has been estimated from thin sections using the method proposed by Perrin et al. (1995). Shape, structure, nucleus, and degree of protuberance of rhodoliths are described in accordance with the procedure used by Bosellini \& Ginsburg (1971), Bosence (1983a) and Basso et al. (2009).

The taxonomic analysis at family and subfamily levels follows Harvey et al. (2003). The taxonomic analysis at genus level is based on the diagnostic characters defined by botanists (Womersley 1996) and nowadays used insofar as possible by paleobotanists too. In the rhodoliths, the melobesioids include thalli with multiporate conceptacles and non-coaxial core, in which Lithothamnion Heydrich cannot be discriminated from Phymatolithon Foslie because the epithallial cells and the immediate inward derivatives of the subepithallial initials are not observable. We use Lithothamnion/Phymatolithon to indicate these thalli. 
TABLE 1. - Taxonomic composition of the non-geniculate calcareous red algae of the Attard member.

\begin{tabular}{|c|c|c|c|c|}
\hline & Inner ramp & & Middle ramp & \\
\hline $\begin{array}{l}\text { Spongites cf. albanensis } \\
\text { Lithoporella melobesioides (Foslie) Foslie, } 1909 \\
\text { Karpathia sphaerocellulosa Maslov, } 1962 \\
\text { Mastophoroideae spp. }\end{array}$ & $\begin{array}{l}\text { Mastophoroideae } \\
19.92 \%\end{array}$ & $\begin{array}{r}11.36 \% \\
4.98 \% \\
0.17 \% \\
3.41 \% \\
\end{array}$ & $\begin{array}{l}\text { Mastophoroideae } \\
12.16 \%\end{array}$ & $\begin{array}{l}4.20 \% \\
5.67 \% \\
2.29 \% \\
\end{array}$ \\
\hline $\begin{array}{l}\text { Lithothamnion roveretoi Airoldi, } 1932 \\
\text { Lithothamnion/Phymatolithon sp. } 1 \\
\text { Lithothamnion/Phymatolithon sp. } 2 \\
\text { Lithothamnion/Phymatolithon sp. } 3 \\
\text { Phymatolithon sp. } \\
\text { Melobesioideae spp. }\end{array}$ & $\begin{array}{l}\text { Melobesioideae } \\
30.74 \%\end{array}$ & $\begin{array}{r}10.48 \% \\
8.47 \% \\
1.83 \% \\
\\
5.06 \% \\
4.90 \% \\
\end{array}$ & $\begin{array}{l}\text { Melobesioideae } \\
27.56 \%\end{array}$ & $\begin{array}{l}8.84 \% \\
2.36 \% \\
3.46 \% \\
5.90 \% \\
5.52 \% \\
1.48 \% \\
\end{array}$ \\
\hline $\begin{array}{l}\text { Sporolithon sp. } 1 \\
\text { Sporolithon sp. } 2\end{array}$ & $\begin{array}{l}\text { Sporolithaceae } \\
31.61 \%\end{array}$ & $\begin{array}{r}31.09 \% \\
0.52 \% \\
\end{array}$ & $\begin{array}{l}\text { Sporolithaceae } \\
50.25 \%\end{array}$ & $\begin{array}{l}19.23 \% \\
31.02 \% \\
\end{array}$ \\
\hline Polystrata alba (Pfender) Denizot, 1968 & $17.73 \%$ & & $10.03 \%$ & \\
\hline
\end{tabular}

TABLE 2. - Morphological and structural characteristics of the rhodoliths of the Attard member.

\begin{tabular}{lll}
\hline & Inner ramp & Middle ramp \\
\hline Shape & ellipsoidal $78 \%$ & ellipsoidal $80 \%$ \\
& subspheroidal $22 \%$ & subspheroidal $16 \%$ \\
& & discoidal $4 \%$ \\
\hline
\end{tabular}

Size $\quad$ ellipsoidal: major axis: $2-5 \mathrm{~cm}(\mathrm{M}=3.1 \mathrm{~cm})$; minor axis: $1.2-4 \mathrm{~cm}(\mathrm{M}=2.3 \mathrm{~cm})$. subspheroidal: diameter: $1.2-2.5 \mathrm{~cm}(\mathrm{M}=1.7 \mathrm{~cm})$.

Nucleus $72.3 \%$ bioclastic sediment $22.2 \%$ lumpy or fruticose coralline thalli $5.5 \%$ coral fragment

Structure $50 \%$ laminar (of which $44.5 \%$ is concentric), passing locally to laminar/columnar (22.2\%);

$33.3 \%$ columnar/branching (III or rarely IV group) passing to laminar; ellipsoidal: major axis: $1.3-5 \mathrm{~cm}(\mathrm{M}=2.9 \mathrm{~cm})$; minor axis: $1-3.5 \mathrm{~cm}(\mathrm{M}=2.1 \mathrm{~cm})$ subspheroidal: diameter $1-4 \mathrm{~cm}(\mathrm{M}=2.4 \mathrm{~cm})$. discoidal: major axis 3-3.4 cm $(\mathrm{M}=3.2 \mathrm{~cm})$; minor axis: $0.6-1 \mathrm{~cm}(\mathrm{M}=0.8 \mathrm{~cm})$.

$60 \%$ bioclastic sediment $40 \%$ lumpy or fruticose coralline thalli

$48 \%$ laminar/columnar, passing (12\%) locally to laminar and outward to columnar/branching; $32 \%$ laminar (of which $24 \%$ is concentric), passing (26\%) to laminar/columnar or locally to columnar/ branching;

$16.7 \%$ laminar/columnar, passing locally to laminar 20\% columnar/branching (III group) passing (16\%) (5.5\%) or to columnar/branching (5.5\%). locally to laminar or laminar/columnar.

\section{RED ALGAL ASSEMBLAGES}

INNER RAMP: RHODOLITH AND RUDSTONE FACIES The red algal assemblage is represented by geniculate coralline algae, free-living branches and rhodoliths. The intergenicula of geniculate coralline algae are very abundant and can be referred to the tribe Janieae. The unattached thalli have a maximum length of $1.5 \mathrm{~cm}$ with branching density ascribed to the group I-II sensu Bosence (1976, 1983a); occasionally they are coated by encrusting thalli of Lithoporella melobesioides (Foslie) Foslie, 1909. The species producing the most of the free-living branches are Lithothamnion roveretoi Airoldi, 1932 (Fig. 4A) and Lithothamnion/Phymatolithon sp. 1 (Fig. 4B); Phymatolithon sp. (Fig. 4C) has a subordinate role and Lithothamnion/Phymatolithon sp. 2 (Fig. 4D), Sporolithon sp. 1 (Fig. 5A), Sporolithon sp. 2 (Fig. 5B), Spongites cf. albanensis (Lemoine) (Braga et al., 1993) (Fig. 5C) and Melo- 
SSW
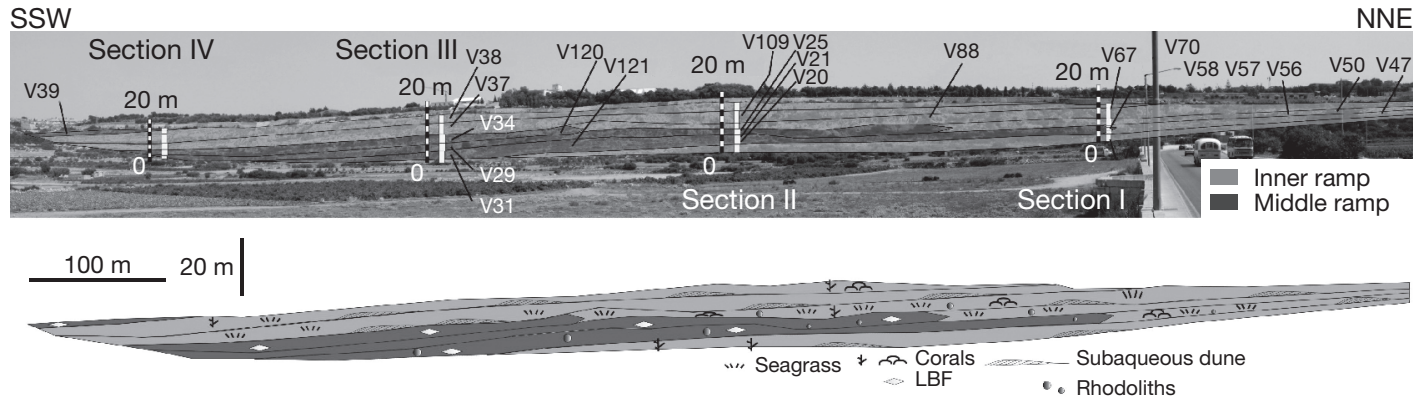

FIG. 3. - Depositional profile of the Attard carbonate ramp (from Brandano et al. 2009a) with location of samples. Abbreviation: LBF, larger benthic foraminifera.

besioideae spp. are rare. In only a few samples are these branches found exclusively or predominate over the rhodoliths.

Among the non-geniculate calcareous red algae (Table 1) Sporolithaceae (31.61\%) and Melobesioideae $(30.74 \%)$ predominate, and Mastophoroideae (19.92\%) and Peyssonneliaceae (17.73\%) are subordinate. Sporolithon sp. 1 is the dominant species of sporolithaceans, while Sporolithon sp. 2 is rare. The melobesioids are represented mainly by L. roveretoi and Lithothamnion/Phymatolithon sp. 1, with Phymatolithon sp., Melobesioideae spp. and Lithothamnion/Phymatolithon sp. 2. less numerous. Most of the mastophoroids are $S$. cf. albanensis while L. melobesioides, Mastophoroideae spp. and Karpathia sphaerocellulosa Maslov, 1962 are rare. Peyssonneliaceans are representented only by Polystrata alba (Pfender) Denizot, 1968 (Fig. 5D).

The majority of the rhodoliths (Table 2 ) are ellipsoidal with subspheroidal shapes subordinate. Among the ellipsoidal specimens major axis range from 2 to $5 \mathrm{~cm}(\mathrm{M}=3.1 \mathrm{~cm})$ and the minor axes from 1.2 to $4 \mathrm{~cm}(\mathrm{M}=2.3 \mathrm{~cm})$. The diameters of the subspheroidal specimens range from 1.2 to $2.5 \mathrm{~cm}(\mathrm{M}=1.7 \mathrm{~cm})$. Most of their nuclei are skeletal grains, with lumpy or fruticose coralline thalli subordinate. Nuclei of coral fragments are rare.

The rhodoliths are monospecific. The inner structure is generally laminar (50\%) with some grading outward to a laminar/columnar structure. The laminar structure is generally concentric and rarely shows loosely packed laminar thalli. Some rhodoliths (33.3\%) have a columnar/branching structure with a branching density of the III or rarely of the IV group that pass outward to a laminar structure. Laminar/columnar structure is less common (16.7\%) and may locally change outward to a laminar or columnar/branching structure.

Table 3 shows the relation between taxonomy and the structure of the nucleus of the rhodolith along with the changes outward to other types of structure.

\section{MidDLE RAMP: RED ALGAL AND BENTHONIC} FORAMINIFERAL FLOATSTONE TO PACKSTONE FACIES In the middle ramp, algal assemblages consist of geniculate coralline algae, free-living branches and rhodoliths, rare $P$. alba that grew in place on the substrate. The intergenicula of the geniculate coralline algae are very abundant and can be referred to the tribe Janieae. The unattached branches with a branching density of the I-II groups occasionally can be oncolitized by encrusting-warty thalli. In the samples studied the free-living branches are less numerous than the rhodoliths. The most abundant species of algae among the free-living branches are L. roveretoi and Sporolithon sp. 2, rare Sporolithon sp. 1, Lithothamnion/Phymatolithon sp.1 and $S$. cf. albanensis. Non-geniculate calcareous red algae (Table 1) include the dominant Sporolithaceae (50.25\%) and Melobesioideae (27.56\%) and the subordinate Mastophoroideae (12.16\%) and Peyssonneliaceae represented by $P$. alba (10.03\%).

Sporolithaceans include Sporolithon sp. 2 and subordinate Sporolithon sp. 1. The melobesioids are represented by $L$. rovereto $i$ and Lithothamnion/ Phymatolithon sp. 3 and Phymatolithon sp.; Litho- 
TABLE 3. - As observed on the inner ramp of the Attard member: the relationship between taxonomic composition and structures of the rhodolith nucleus and of the other types of structure outward. For each type of rhodolith structures on the nucleus and outward is indicated the percentage of rhodoliths in which each coralline species occurs.

\begin{tabular}{|c|c|c|c|c|}
\hline \multirow[b]{2}{*}{ 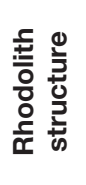 } & \multicolumn{2}{|l|}{ On nucleus } & \multicolumn{2}{|c|}{ Outward on other type of structure } \\
\hline & $\begin{array}{c}\text { identified species } \\
\text { and growth form }\end{array}$ & $\begin{array}{l}\% \text { of rhodoliths } \\
\text { in which each } \\
\text { species oc- } \\
\text { currs }\end{array}$ & $\begin{array}{l}\text { identified species } \\
\text { and growth form }\end{array}$ & $\begin{array}{l}\% \text { of rhodo- } \\
\text { liths in which } \\
\text { each species } \\
\text { occurrs }\end{array}$ \\
\hline \multirow{8}{*}{ 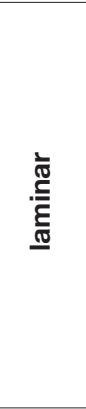 } & $\begin{array}{l}\text { Mastophoroideae spp. } \\
\text { (encrusting or encrusting-warty) }\end{array}$ & 50 & $\begin{array}{l}\text { Lithoporella melobesioides } \\
\text { (encrusting) }\end{array}$ & 40 \\
\hline & Polystrata alba (encrusting) & 50 & Polystrata alba (encrusting) & 40 \\
\hline & Sporolithon sp. 1 (encrusting-warty) & 37.5 & Melobesioideae spp. (encrusting- & 20 \\
\hline & Lithoporella melobesioides & 12.5 & & \multirow{5}{*}{20} \\
\hline & $\begin{array}{l}\text { (encrusting) } \\
\text { Karpathia sphaerocellulosa }\end{array}$ & 12.5 & \multirow{4}{*}{$\begin{array}{l}\text { Sporolithon sp. } 1 \text { (encrusting- } \\
\text { warty) }\end{array}$} & \\
\hline & (encrusting) & & & \\
\hline & $\begin{array}{l}\text { Lithothamnion/Phymatolithon sp. } 1 \\
\text { (encrusting-warty) }\end{array}$ & 12.5 & & \\
\hline & $\begin{array}{l}\text { Melobesioideae spp. } \\
\text { (encrusting-warty) }\end{array}$ & 12.5 & & \\
\hline \multirow{4}{*}{ 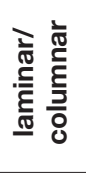 } & Mastophoroideae spp. & 66.6 & \multirow{4}{*}{$\begin{array}{l}\text { Lithothamnion roveretoi (warty) } \\
\text { Lithothamnion/Phymatolithon sp. } 1 \\
\text { (warty-lumpy) } \\
\text { Sporolithon sp. } 1 \text { (warty-lumpy) }\end{array}$} & 50 \\
\hline & (warty or warty-lumpy) & & & \multirow{2}{*}{25} \\
\hline & $\begin{array}{l}\text { Melobesioldeae spp. (warty) } \\
\text { Sporolithon sp. } 1\end{array}$ & 33.3 & & \\
\hline & $\begin{array}{l}\text { Sporolithon sp. } 1 \\
\quad \text { (lumpy or lumpy-fruticose) }\end{array}$ & 33.3 & & 25 \\
\hline \multirow{4}{*}{ 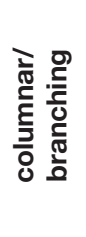 } & $\begin{array}{l}\text { Phymatolithon sp. } \\
\text { (lumpy-fruticose or fruticose) }\end{array}$ & 40 & \multirow[t]{4}{*}{$\begin{array}{l}\text { Spongites cf. albanensis } \\
\quad \text { (lumpy-fruticose) }\end{array}$} & \multirow[t]{4}{*}{100} \\
\hline & Sporolithon sp. 1 (lumpy-fruticose) & 40 & & \\
\hline & $\begin{array}{l}\text { Spongites cf. albanensis } \\
\text { (lumpy-fruticose) }\end{array}$ & 20 & & \\
\hline & $\begin{array}{l}\text { Melobesioideae spp. } \\
\text { (lumpy-fruticose) }\end{array}$ & 20 & & \\
\hline
\end{tabular}

thamnion/Phymatolithon sp. 2, Lithothamnion/ Phymatolithon sp. 1 and Melobesioideae spp. are subordinate. Lithoporella melobesioides and Spongites cf. albanensis, predominate among the mastophoroids. Other Mastophoroideae spp. are rare.

Most rhodoliths (Table 2) are ellipsoidal, rarely subspheroidal and discoidal. In the ellipsoidal rhodolith the major axis ranges from 1.3 to $5 \mathrm{~cm}$ $(\mathrm{M}=2.9 \mathrm{~cm})$ and the minor axis from 1 to $3.5 \mathrm{~cm}$ $(\mathrm{M}=2.1 \mathrm{~cm})$; the diameter of the subspheroidal rhodoliths ranges from 1 to $4 \mathrm{~cm}(\mathrm{M}=2.4 \mathrm{~cm})$ and in the discoidal rhodoliths the major axis ranges from 3 to $3.4 \mathrm{~cm}(\mathrm{M}=3.2)$ and the short axis from 0.6 to $1 \mathrm{~cm}(\mathrm{M}=0.8 \mathrm{~cm})$. Most cores are skeletal grains, only rarely are they lumpy or fruticose coralline thalli.
Rhodoliths are multispecific. The most common structure (48\%) is laminar/columnar locally passing to laminar and outward to columnar/branching. An initial laminar structure (32\%) commonly is replaced outward by a laminar/columnar structure or locally by a columnar/branching arrangement. Most laminae are concentric and are rarely represented by loosely packed laminar thalli. When compared to the several types of structure developed outward, the laminar part of the nucleus is developed meagrely. Some rhodoliths $(20 \%)$ are columnar/branching structures, their branching density of the III group passing outward locally to laminar or laminar/columnar thalli.

Table 4 shows the relationship between species and growth forms at the nucleus and outward. 

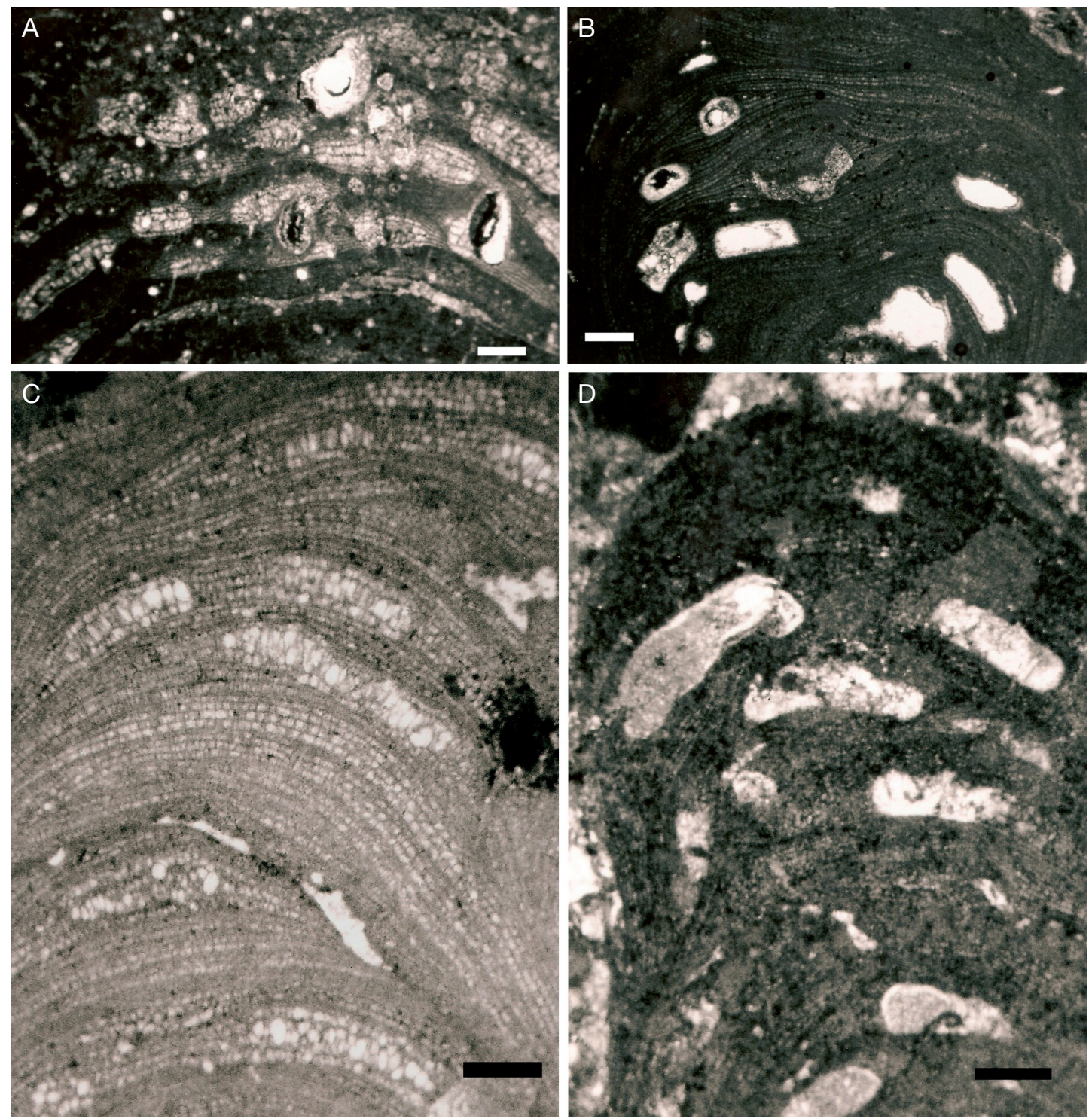

FIG. 4. - A, Lithothamnion roveretoi Airoldi, 1932, transmitted light optical microscope (OM) photograph, thin section no. 4 (sample V20d, middle ramp); B, Lithothamnion/Phymatolithon sp. 1., OM photograph, thin section 17 (sample V56, inner ramp); C, Phymatolithon sp., OM photograph, thin section 10 (sample V37a, inner ramp); D, Lithothamnion/Phymatolithon sp. 2, OM photograph, thin section 18 (sample V57, inner ramp). Scale bars: $250 \mathrm{~mm}$.

\section{DISCUSSION}

\section{WATER TEMPERATURE}

Coralline algal assemblages may be used to infer paleoclimatic conditions (Bosence 1983b; Aguirre et al. 2000; Braga \& Aguirre 2001; Piller 2003). A high percentage of Sporolithon and the presence of Lithoporella in the assemblages indicate that carbonate production took place in tropical waters (Bosence 1983b, 1991; Adey 1986; Braga \& Aguirre 2001; 
TABLE 4. - As observed on the middle member of the Attard ramp: the relationship between taxonomic composition and structures of the rhodolith nucleus and of other types of structure outward. For each type of rhodolith structure on the nucleus and outward is indicated the percentage of rhodoliths in which each coralline species occurs.

\begin{tabular}{|c|c|c|c|c|}
\hline \multirow[b]{2}{*}{ 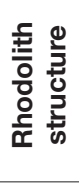 } & \multicolumn{2}{|l|}{ On nucleus } & \multicolumn{2}{|c|}{ Outward on other type of structure } \\
\hline & $\begin{array}{l}\text { identified species } \\
\text { and growth form }\end{array}$ & $\begin{array}{l}\% \text { of rhodo- } \\
\text { liths in which } \\
\text { each species } \\
\text { occurrs }\end{array}$ & $\begin{array}{l}\text { identified species } \\
\text { and growth form }\end{array}$ & $\begin{array}{l}\% \text { of rhodo- } \\
\text { liths in which } \\
\text { each species } \\
\text { occurrs }\end{array}$ \\
\hline \multirow{4}{*}{ 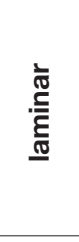 } & $\begin{array}{l}\text { Lithoporella melobesioides } \\
\text { (encrusting) }\end{array}$ & 100 & Polystrata alba (encrusting) & 66.6 \\
\hline & $\begin{array}{l}\text { Spongites cf. albanensis } \\
\text { (encrusting-warty) }\end{array}$ & 14.3 & $\begin{array}{l}\text { Lithoporella melobesioides (en- } \\
\text { crusting) }\end{array}$ & 50 \\
\hline & $\begin{array}{l}\text { Mastophoroideae spp. (encrusting- } \\
\text { warty) }\end{array}$ & 14.3 & Mastophoroideae spp. (encrusting) & 33.3 \\
\hline & Polystrata alba (encrusting) & 14.3 & & \\
\hline \multirow{10}{*}{ 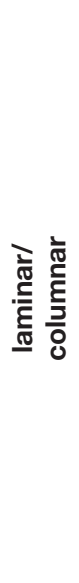 } & $\begin{array}{l}\text { Lithoporella melobesioides } \\
\quad \text { (encrusting) }\end{array}$ & 58.3 & Lithothamnion roveretoi (warty) & 66.6 \\
\hline & $\begin{array}{l}\text { Sporolithon sp. } 2 \\
\text { (encrusting-warty to warty-lumpy) }\end{array}$ & 41.6 & Sporolithon sp. 1 (warty-lumpy) & 66.6 \\
\hline & $\begin{array}{l}\text { Spongites cf. albanensis } \\
\text { (encrusting-warty to warty-lumpy) }\end{array}$ & 16.6 & Sporolithon sp. 2 (warty-lumpy) & 33.3 \\
\hline & Mastophoroideae spp. (warty) & 16.6 & & \\
\hline & $\begin{array}{l}\text { Lithothamnion roveretoi } \\
\text { (encrusting-warty to warty-lumpy) }\end{array}$ & 16.6 & & \\
\hline & $\begin{array}{l}\text { Lithothamnion/Phymatolithon sp. } 3 \\
\text { (encrusting-warty to warty) }\end{array}$ & 16.6 & & \\
\hline & Melobesioideae spp. (warty-lumpy) & 16.6 & & \\
\hline & $\begin{array}{l}\text { Lithothamnion/Phymatolithon sp. } 1 \\
\text { (warty) }\end{array}$ & 8.3 & & \\
\hline & $\begin{array}{l}\text { Lithothamnion/Phymatolithon sp. } 2 \\
\quad \text { (warty-lumpy) }\end{array}$ & 8.3 & & \\
\hline & Polystrata alba (encrusting) & 8.3 & & \\
\hline \multirow{8}{*}{ 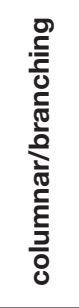 } & Spongites cf. albanensis (lumpy) & 20 & Lithothamnion roveretoi (lumpy) & 40 \\
\hline & Mastophoroideae spp. (lumpy) & 20 & Lithothamnion/Phymatolithon sp. 1 & 40 \\
\hline & Lithothamnion roveretoi (lumpy) & 20 & (lumpy-fruticose) & \\
\hline & Lithothamnion/Phymatolithon sp. 1 & 20 & Sporolithon sp. 1 (lumpy-fruticose) & 40 \\
\hline & (lumpy-fruticose) & & Sporolithon sp. 2 (lumpy-fruticose) & 40 \\
\hline & Phymatolithon sp. (lumpy-fruticose) & 20 & & \\
\hline & $\begin{array}{l}\text { Sporolithon sp. } 1 \\
\text { (warty-lumpy to lumpy-fruticose) }\end{array}$ & 20 & & \\
\hline & Sporolithon sp. 2 (lumpy-fruticose) & 20 & & \\
\hline
\end{tabular}

Piller 2003). Tropical conditions are also supported by the presence of scattered coral colonies in inner ramp settings and by the assemblages of larger benthic foraminifers including Sorites, Peneroplis de Montfort, 1808 and Archaias. Such climatic conditions are confirmed by paleolatitudinal reconstructions that place the Maltese islands south of $30^{\circ} \mathrm{N}$ during most of the Oligocene (33.1 Ma)
(Brandano et al. 2009b). This position is analogous to the present-day northern Red Sea, where corals and photozoan skeletal assemblage dominate (cf. Piller \& Monseur 1990; Riegl \& Piller 1999).

\section{Hydrodynamism}

Bosellini \& Ginsburg (1971) and Bosence (1991) show that rhodoliths are sensitive indicators of 

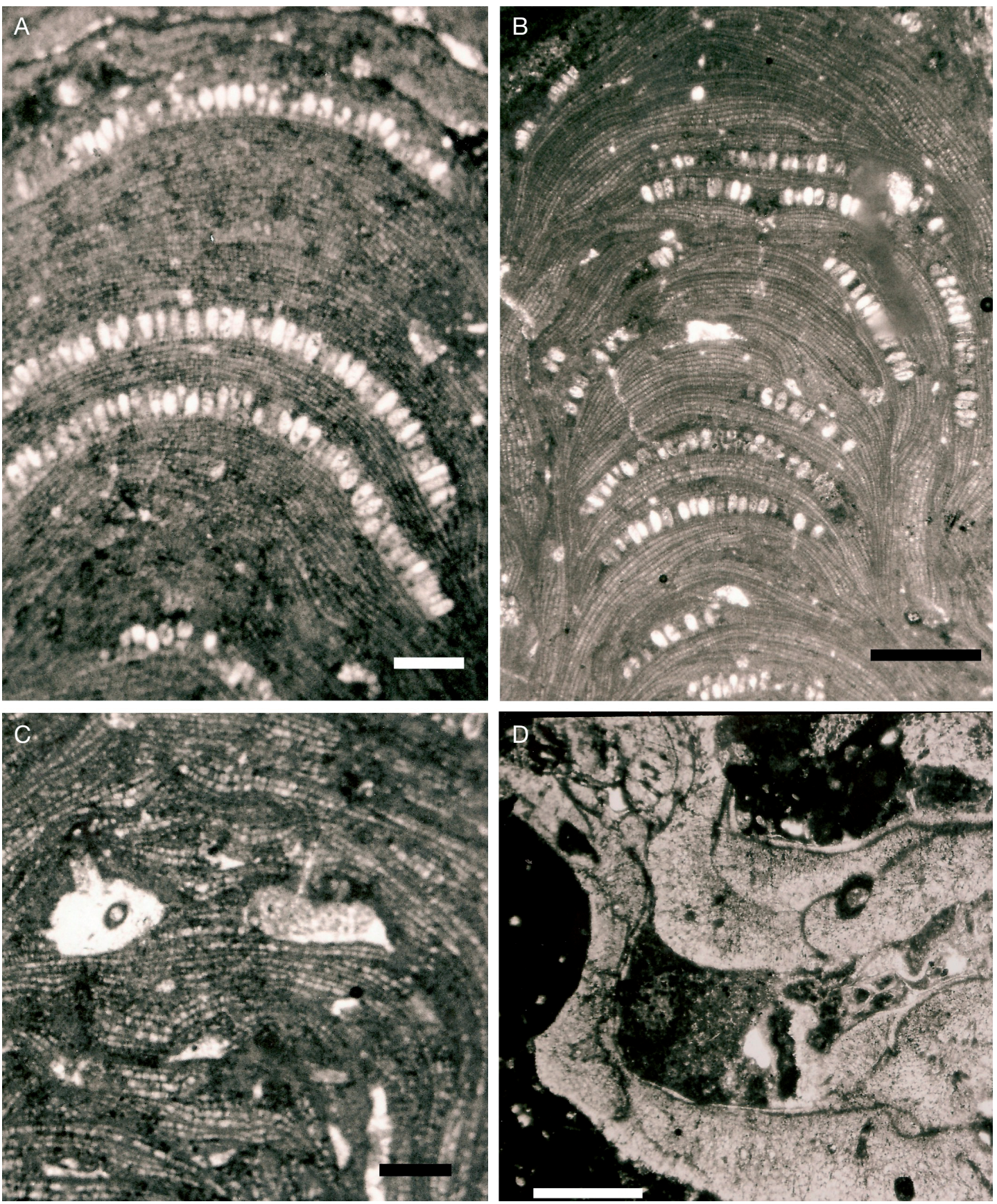

FIG. 5. - A, Sporolithon sp. 1., transmitted light optical microscope (OM) photograph, thin section 13 (sample V38b, inner ramp); B, Sporolithon sp. 2, OM photograph, thin section 2 (sample V20b, middle ramp); C, Spongites cf. albanensis (Lemoine) (Braga et al., 1993), OM photograph, thin section 10 (sample V37a, inner ramp); D, Polystrata alba (Pfender) Denizot, 1968, OM photograph, thin section 3 (sample V20c, middle ramp). Scale bars: A, C, 250 mm; B, D, 600 mm. 
hydrodynamic conditions in existing shallow-water marine environments, however bottom-dwelling organisms could move the rhodoliths (Steneck 1986; Prager \& Ginsburg 1989; Marrack 1999). In many settings bioturbation may replace the movement of water as a mechanism for rhodolith production. In the studied example the main agent for the transport of rhodoliths may be considered to be water energy because they formed in a high energy depositional environments placed above FWWB (inner ramp) and above SWB (middle ramp) as suggested by textural and compositional characters of sediments (Brandano et al. 2009a).

The dominance in the inner ramp of a concentric laminar structure of rhodoliths together with the prevalence of columnar/branching with branching densities of the III and rarely the IV group that grade outward to laminar structure, are characteristic of high-energy conditions.

Furthermore, the high percentage in some samples of free-living branches, with branching density of the I-II groups, suggests two discrete hydrodynamic conditions in the inner ramp setting where rhodoliths grew. A first zone characterized by a high hydrodynamic energy and a second zone with lower hydrodynamic energy colonized by maerl.

On the other hand the carbonate factory of the inner ramp is a spatially complex mosaic where patches of seagrass are adjacent to erosional blow-outs each with a different balance between production and loss of sediment (cf. Wright \& Burgess 2005). These elements of the mosaic are not static; they move over time reflecting more or less subtle shifts in the level of energy and other factors (seagrass health and the rate of production of epiphytic carbonates).

The high percentage of laminar/columnar rhodoliths and the columnar/branching structures in the middle ramp suggest that hydrodynamic conditions are moderate to high. Mastophoroids and rare Polystrata alba (Table 4) form the laminar structure on the nucleus of rhodoliths. These structures pass outward to different structures, suggesting a downward transfer of small laminar rhodoliths from the inner ramp (Table 3) into the middle ramp. Rhodoliths kept on growing with laminar/columnar or locally columnar/branching structures (Table 2) and algal assemblages with only melobesioids and sporolithaceans (Table 4) in lower energy deeper waters. This interpretation is consistent with that of Brandano et al. (2009a) who assert that sediment accumulation of the middle ramp is the result of production in situ and material swept down from the shallower inner ramp.

\section{Paleodepth}

Since the 1980s, assemblages of coralline algae have been used to infer the paleo water depth of sedimentary environments (Bosence 1983a; Adey 1986; Steneck 1986).

The comparison between the algal associations of inner and middle ramp evidences an increase of the sporolithaceans family $(18.64 \%)$ and a low decrease of mastophoroids $(7.76 \%)$ moving from the inner to the middle environment. This different taxonomic composition in the different depositional settings of the ramp is related to the proximal/distal (depth) gradient existing from the inner to the middle ramp. The moderate decrease of Polystrata alba $(7.70 \%)$ does not fit precisely into this gradient, because some modern examples of peyssonneliacean algae are found at depths greater than those favored by coralline algae, and this general trend was also reported in Eocene examples (Rasser 1994, 2000; Rasser \& Piller 2004). Extant peyssonneliaceans are known from tropical to polar latitudes, mainly from depths ranging between 0.5 and $50 \mathrm{~m}$. However they have been dredged from $120 \mathrm{~m}$ wd (James et al. 1988; Kato et al. 2006). Several studies (see Kato et al. 2006; Guiry \& Guiry 2008 and references therein) point out that the genus Polystrata is present in tropical to temperate waters of the Indian, Pacific and Atlantic oceans and the Mediterranean Sea at depths ranging between 0.5 and 20-25 $\mathrm{m}$ wd. So the abundance of $P$. alba on inner ramp environments accords with the ecological requirements of extant Polystrata. Little is known about the rhodolith structures of the still extant Polystrata alba. Polystrata alba in the Attard member ramp mainly contribute to form the concentric laminar structure of multispecific rhodoliths. These kind of rhodoliths are fully comparable with the 
peyssonneliacean species Polystrata alba from the Late Eocene of the Austrian Alpine Foreland Basin forming with continuous reworking conditions leading to "growth stage 4" sensu Rasser (2001). This comparison is consonant with the hydrodynamic considerations described for the Attard member.

The bathymetric information obtained from the encrusting Corallinales and Sporolithales in the inner ramp by using the classical interpretation (Adey 1979, 1986; Bosence 1991) suggest a shallow depositional environment in the photic zone.

On the middle ramp the pronounced dominance of sporolithaceans and the contemporaneous decrease of mastophoroids suggest that photic conditions were less intense than those of the inner ramp.

Geniculate coralline algae are broadly diffused in both the inner and middle ramp lithofacies; they mostly occur as disarticulated forms which are well preserved in the proximal lithofacies represented by the porcelaneous foraminiferal grainstone to packstone facies (Brandano et al. 2009a). Wray (1977) suggests that geniculate species generally reach their maximum abundance in water less than $10 \mathrm{~m}$ deep.

\section{Oligocene red algal carbonate factory}

The carbonate factory of the Attard member ramp in both the inner and middle ramp environments was dominated by heterozoan skeletal assemblages (Brandano et al. 2009a, b). The biotic assemblages of the Attard member and palaeolatitudinal reconstruction of the Maltese islands during Late Oligocene times suggest that carbonate sedimentation took place in tropical waters, under oligotrophic to slightly mesotrophic conditions (Brandano et al. $2009 \mathrm{~b}$ ). These conditions should have promoted the coral rich photozoan factory. Below, we summarize the several factors that may have controlled the spreading of the coralline algae factory from the Oligocene to the Miocene.

An increase in the percentage of $\mathrm{CO}_{2}$ in the atmosphere is a critical factor that promotes calcite precipitation over aragonite (Stanley \& Hardie 1998; Basso 2012). During Late Oligocene and Miocene the atmospheric $\mathrm{CO}_{2}$ concentration were similar (Pearson \& Palmer 2000) suggesting that $\mathrm{CO}_{2}$ had little effect on the aragonite-dominated photozoan factory. Some authors evidenced the coincidence of a major drop of $\mathrm{CO}_{2}$ during Early Oligocene with the disappearance of nummulitids and expansion of $\mathrm{C}^{4}$ terrestrial plants on land, in response to stresses associated with photorespiration (Pomar \& Hallock 2008). Coralline red algae thrived and increased in diversity during the Oligocene, exhibiting a large species richness (Aguirre et al. 2000), and becoming the dominant carbonate-sediment producer (Halfar \& Mutti 2005) during the Early and Middle Miocene at global scale (Pomar \& Hallock 2008).

A possible controlling factor in the diffusion of red algae during the Oligocene may have been the $\mathrm{Mg} / \mathrm{Ca}$ ratio in seawater. Stanley \& Hardie (1998) showed that the combination of higher $\mathrm{Ca}^{2+}$ concentrations and lower $\mathrm{Mg} / \mathrm{Ca}$ ratios in the oceans favoured calcite precipitation over that of aragonite whereas atmospheric $\mathrm{CO}_{2}$ concentrations did not influence the carbonate precipitation. These authors suggest that since Oligocene times the $\mathrm{Mg} / \mathrm{Ca}$ ratio of seawater has not been high enough to permit aragonitic reefs to flourish. On the contrary, during the Early Paleogene coralline algae flourished as never before, because they tolerate a lower $\mathrm{Mg} / \mathrm{Ca}$ ratio to form their $\mathrm{Mg}$-calcite thalli with respect to aragonitic corals (Ries 2010).

Brandano et al. (2009a, b) suggested that the spread of heterozoan assemblages in the Late Oligocene of Malta seems to be related to the palaeoecology of the zooaxanthellate corals which until the Late Miocene were not able to build three-dimensional wave-resistant structures to sea level but lived in the middle and lower photic zone (Pomar \& Hallock 2007). The low capacity of corals to thrive in highlight conditions and to form wave-resistant reefs promoted the diffusion of heterozoan assemblages dominated by LBF and coralline algae, the two main components of biogenic sediments of Miocene carbonate platforms.

During the Early and Middle Miocene coralline algae predominated in the carbonate factories (Halfar \& Mutti 2005; Pomar \& Hallock 2008). The spreading of these biota during the Miocene was related to the higher surface-water productivity induced by increased runoff of land-derived nutrients and by enhanced upwelling resulting from increased thermal gradients and thermohaline circulation (Halfar \& Mutti 2005). 


\section{CONCLUSION}

The red algal assemblages of the Attard member are related to the proximal/ distal (shallow/deep) gradient existing from the inner to the middle ramp. However, the measured percentages of the genera and species of red algae should be analysed with caution because downslope transport may affect the red algae associations as well as rhodolith size, structure, and growth of individual rhodoliths.

On the inner ramp the rhodoliths are monospecific, commonly ellipsoidal, infrequently subspheroidal. Their inner structure is generally laminar passing outward to laminar/columnar. Only a minor percentage of rhodoliths is characterized by a columnar/branching that passes outward to a laminar structure. These characteristics are indicative of a high-energy environment, confirmed by the cross-bedded grainstones in the shallower part of the inner ramp. Localized sectors of inner ramp were characterized by structure typical of low energy (branch I and II groups), may be related to the presence of areas colonized by seagrass.

Rhodoliths from the middle ramp are multispecific and most are ellipsoidal in shape, rarely subspheroidal and discoidal. The structure is predominantly laminar/columnar locally passing to laminar and outward to columnar/branching. Rhodoliths with laminar structure are also common. All are characteristics of moderately high-energy environments. The accumulation of sediment in the middle ramp are a combination of in situ production and sediments swept from the shallower inner ramp by waves and currents.

There is no evidence of bioturbation activity in rhodolith formation. The presence of Sporolithon and Lithoporella indicates that carbonate production took place under tropical conditions.

Rising of $\mathrm{Mg} / \mathrm{Ca}$ ratio favoured the flourishing of coralline algae in the Oligocene factories, also in the oligo- to mesotrophic conditions of the Attard ramp development. Successively, during Early to Middle Miocene, the trophic condition was one of the main controlling factor, since the surface-water productivity favoured this oligophotic, sediment-producing biota.

\section{Acknowledgements}

This work was supported by Progetti di Università La Sapienza (Resp MB). Laura Tomassetti was funded by IAS postgraduate grant (2009). We thank Ioan Bucur, André Strasser and Valéry Malécot for their thoughtful and constructive reviews of the manuscript.

\section{REFERENCES}

Adams C. G., Lee D. E. \& Rosen B. R. 1990. — Conflicting isotopic and biotic evidence for tropical sea-surface temperatures during the Tertiary. Palaeogeography, Palaeoclimatology, Palaeoecology 77 (3-4): 289-313.

ADEY W. H. 1979. - Crustose coralline algae as microenvironmental indicators for the Tertiary, in GRAY J. \& Boucot A. J. (eds), Historical Biogeography, Plate Tectonics, and the Changing Environment. Oregon State University Press, Corvallis: 459-464.

ADEY W. H. 1986. - Coralline algae as indicators of sea-level, in VAN DE Plasche O. (ed.), Sea-Level Research: a Manual for the Collection and Evaluation of Data. Geo Books, Norwich: 229-280.

Aguirre J., Riding R. \& Braga J. C. 2000. — Diversity of coralline red algae: origination and extinction patterns from the Early Cretaceous to the Pleistocene. Palebiology 26 (4): 651-667.

AguirRe J., BACETA J. I. \& BRAGA J. C. 2007. — Recovery of marine primary producers after the CretaceousTertiary mass extinction: Paleocene calcareous red algae from the Iberian Peninsula. Palaeogeography, Palaeoclimatology, Palaeoecology 249 (3-4): 393-411.

Airoldi M. 1932. - Contributo allo studio delle Corallinacee del terziario italiano. I. Le Corallinacee dell'Oligocene ligure-piemontese. Palaeontographia Italica 33: 55-83.

AsHLEy G. M. 1990. - Classification of large-scale subaqueous bedforms: a new look at an old problem. Journal of Sedimentary Petrology 60 (1): 160-172.

BASSO D. 1998. - Deep rhodolith distribution in the Pontian Islands, Italy: a model for the paleoecology of a temperate sea. Palaeogeography, Palaeoclimatology, Palaeoecology 137 (1-2): 173-187.

BASSO D. 2012. — Carbonate production by calcareous red algae and global change, in BASSO D. \& GRANIER B. (eds), Calcareous algae and global change: from identification to quantification. Geodiversitas 34 (1): 13-33. http://dx.doi.org/10.5252/g2012n1a2

Basso D., NALIN R. \& NelsOn C. S. 2009. - Shallowwater Sporolithon rhodoliths from North Island (New Zealand). Palaios 24 (2): 92-103.

Bosellini A. \& Ginsburg R. N. 1971. - Form and internal structure of recent algal nodules (rhodolithes) 
from Bermuda. Journal of Geology 79: 669-682.

Bosence D. W. J. 1976. - Ecological studies on two unattached coralline algae from western Ireland. Paleontology 19 (2): 365-395.

Bosence D. W. J. 1983a. - Description and classification of rhodoliths (rhodoids, rhodolites), in PERYT T. M. (ed.), Coated Grains. Springer-Verlag, Berlin: 217-224.

Bosence D. W. J. 1983b. - The ocurrence and ecology of recent rhodoliths, in PERYT T. M. (ed.), Coated Grains. Springer-Verlag, Berlin: 225-242.

Bosence D. W. J. 1991. — Coralline algae: mineralization, taxonomy and palaeoecology, in RIDING R. (ed.), Calcareous Algae and Stromatolites. Springer, Berlin: 98-113.

Braga J. C. \& Aguirre J. 2001. - Coralline algal assemblages in Upper Neogene reef and temperate carbonates in southern Spain. Palaeogeography, Palaeoclimatology, Palaeoecology 175 (1-4): 27-41.

BRAgA J. C., BoSENCE D. W. J. \& STENECK R. S. 1993. New anatomical characters in fossil coralline algae and their taxonomic implications. Palaeontology 36 (3): 535-547.

Brandano M., Vannucci G., Pomar L. \& ObraDOR A. 2005. - Rhodolith assemblages from the lower Tortonian carbonate ramp of Menorca (Spain): Environmental and paleoclimatic implications. Palaeogeography, Palaeoclimatology, Palaeoecology 226 (3-4): 307-323.

Brandano M., Frezza V., Tomassetti L., Pedley M. \& Matteucci R. 2009a. - Facies anlaysis and palaeoenvironmental interpretation of the Late Oligocene Attard Member (Lower Coralline Limestone Formation), Malta. Sedimentology 56 (4): 1138-1158.

BRANDANO M., Frezza V., TOMASSETti L. \& CUfFaro M. 2009b. - Heterozoan carbonates in oligotrophic tropical waters: the Attard Member of the Lower Coralline Limestone Formation (Upper Oligocene, Malta). Palaeogeography, Palaeoclimatology, Palaeoecology 274 (1-2): 54-63.

Carannante G., Cherchi A. \& Simone L. 1995. Chlorozoan versus foramol lithofacies in Upper Cretaceous rudist limestones. Palaeogeography, Palaeoclimatology, Palaeoecology 119 (1-2): 137-154.

Carbone S., Grasso M., Lentini F. \& Pedley H.M. 1987. - The distribution and palaeoenvironment of Early Miocene phosphorites of southeast Sicily and their relationships with the Maltese phosphorites. Palaeogeography, Palaeoclimatology, Palaeoecology 58 (1-2): 35-53.

Denizot M. 1968. - Les algues floridées encroûtantes (à l'exclusion des Corallinacées). Thèse, Laboratoire de cryptogamie, Muséum national d'Histoire naturelle, Paris, $310 \mathrm{p}$.

Di Geronimo I., Grasso M. \& Pedley H. M. 1981. — Palaeoenvironment and palaeogeography of Miocene marls from Southeast Sicily and the Maltese Islands. Palaeogeography. Palaeoclimatology, Palaeoecology 34: 173-189.

FosLIE M. 1909. - Algologiske notiser. VI. Kongelige Norske Videnskabers Selskabs Skrifter 2: 1-63.

Foster M. S., Riosmena-Rodriguez R., Steller D. L. \& WOELKERLING W. J. 1997. — Living rhodoliths beds in the Gulf of California and their implication for paleoenvironmental interpretation, in JOHNSON M. E. \& LeDESMA-VASQUEZ J. (eds), Pliocene carbonates and related facies flanking in the Gulf of California, Baja California, Mexico. Geological Society of America Special Paper 318: 127-139.

GuirY M. D. \& GuirY G. M. 2008. — Algae Base. Worldwide electronic publication, National University of Ireland, Galway. http://www.algaebase.org

Halfar J. \& MutTi M. 2005. - Global dominance of coralline red-algal facies: a response to Miocene oceanographic events. Geology 33 (6): 481-484.

Harvey A. S., BroadWATER S. T., WoelKerling W. J. \& MitROVSKI P. J. 2003. - Choreonema (Corallinales, Rhodophyta): $18 \mathrm{~S}$ rDNA phylogeny and resurrection of the Hapalidiaceae for the subfamily Choreonematoideae, Austrolithoideae, and Melobesioideae. Journal of Phycology 39 (5): 988-998.

James N. P., WRAY J. L. \& Ginsburg R. N. 1988. Calcification of encrusting aragonitic algae (Peyssonneliaceae) implications for the origin of the Late Paleozoic reefs and cements. Journal of Sedimentary Petrology 58 (2): 291-303.

Kato A., Baba M., KaWai H. \& Masuda M. 2006. Reassessment of the little-known crustose red algal genus Polystrata (Gigartinales), based on morphology and SSU rDNA sequences. Journal of Phycology 42 (4): 922-933.

MARRACK E. C. 1999. - The relationship between water motion and living rhodolith beds in the southwestern Gulf of California, Mexico. Palaios 14 (2): 159-171.

MASLOV V. P. 1962. - [Fossil red algae of USSR and their connection with facies]. Trudy Institut Geologicheskiy, Akademiya Nauk SSSR 53: 1-221 (in Russian).

Pearson P. N. \& Palmer M. R. 2000. - Atmospheric carbon dioxide concentrations over the past 60 million years. Nature 406: 695-699.

Pedley H. M. 1978. - A new lithostratigraphical and palaeoenvironmental interpretation for the coralline limestone formations (Miocene) of the Maltese islands. Overseas, Geology and Mineral Resources 54: 273-291.

Pedley H. M. 1998. - A review of sediment distributions and processes in Oligo-Miocene ramps of southern Italy and Malta (Mediterranean divide), in Wright V. P. \& Burchette T. P. (eds), Carbonate ramps. Geological Society of London, Special Publication 149: 163-179.

Perrin C., Bosence D. \& Rosen B. 1995. - Quantitative approaches to palaeozonation and palaeobathym- 
etry of corals and coralline algae in Cenozoic reefs, in Bosence D. W. J. \& Aluison P. A. (eds), Marine palaeoenvironmental analysis from fossils. Geological Society of London, Special Publication 83: 181-229.

PILLER W. E. 2003. — Miocene carbonates in the western central Paratethys, an unexpected development, in BASSI D. (ed.), Oligo-Miocene shallow water carbonates: biogenic components and facies. Annali dell'Università di Ferrara, sezione Scienze della Terra 10: 19-20.

Piller W. E. \& Monseur A. 1990. - The northern Bay of Safaga (Red Sea, Egypt): an actuopalaeontological approach. II. Sediment analyses and sedimentary facies. Beiträge zur Paläontologie Österreich 16: 1-102.

POMAR L. \& HALLOCK P. 2007. - Changes in coral-reef structure through the Miocene in the Mediterranean province: adaptive vs. environmental influence. Geology 35 (10): 899-902.

Pomar L. \& Hallock P. 2008. — Carbonate factories: A conundrum in sedimentary geology. Earth-Science Reviews 87 (3-4): 134-169.

Pomar L., Obrador A. \& Westphal H. 2002. Sub-wavebase cross-bedded grainstones on a distally steepened carbonate ramp, Upper Miocene, Menorca, Spain. Sedimentology 49 (1): 139-169.

Prager E. J. \& Ginsbug R. N. 1989. - Carbonate nodule growth on Florida's outer shelf and its implications for fossil interpretations. Palaios 4 (4): 310-317.

RASSER M. W. 1994. - Facies and palaeoecology of the rhodoliths and acervulinid macroids in the Eocene of the Krappfeld (Austria). Beiträge zur Paläontologie 19: 191-217.

RASSER M. W. 2000. - Coralline red algal limestones of the Late Eocene alpine foreland basin in upper Austria: component analysis, facies and palaeoecology.
Facies 42 (1): 59-92.

Rasser M. W. 2001. - Paleoecology and taphonomy of Polystrata alba (Red Alga) from the Late Eocene Alpine Foreland: a new tool for the reconstruction of sedimentary environments. Palaios 16 (6): 601-607.

Rasser M. W. \& Piller W. E. 2004. — Crustose algal frameworks from the Eocene Alpine Foreland. Palaeogeography, Palaeoclimatology, Palaeoecology 206 (1-2): 21-39.

Riegl B. \& PilLER W. E. 1999. - Framework revisited: reefs and coral carpets of the northern Red Sea. Coral Reefs 18 (3): 305-316.

RIES J. B. 2010. - Review: geological and experimental evidence for secular variation in seawater $\mathrm{Mg} / \mathrm{Ca}$ (calcite-aragonite seas) and its effects on marine biological calcification. Biogeosciences 7: 2795-2849.

Stanley S. M. \& Hardie L. A. 1998. - Secular oscillations in the carbonate mineralogy of reef-building and sediment-producing organisms driven by tectonically forced shifts in seawater chemistry. Palaeogeography, Palaeoclimatology, Palaeoecology 144 (1-2): 3-19.

STENECK R. S. 1986. - The ecology of coralline algal crusts: convergent patterns and adaptative strategies. Annual Review of Ecology and Systematics 17: 273-303.

Womersley H. B. S. 1996. - The Marine Benthic Flora of Southern Australia, Rhodophyta. Part III B. Gracilariales, Rhodymeniales, Corallinales and Bonnemaisoniales. Australian Biological Resources Study, Canberra, 392 p.

Wray J. L. 1977. - Calcareous Algae. Elsevier, Amsterdam, $185 \mathrm{p}$.

WRight V. P. \& BURgess P. M. 2005. — The carbonate factory continuum, facies mosaics and microfacies: an appraisal of some of the key concepts underpinning carbonate sedimentology. Facies 51 (1-4): 17-23.

Submitted on 9 May 2011; accepted on 7 December 2011. 